\title{
Surface agents' influence on the flexural strength of bilaminated ceramics
}

Júlia Magalhães Costa Lima(a)
Lilian Costa Anami $^{(a)}$
Marília Pivetta Rippe
Renata Marques de Melo(b)
Marco Antonio Bottino(b)
Márcia Carneiro Valera
Maria Amélia Máximo Araújo(c)

(a) Graduate Program in Restorative Dentistry, Instituto de Ciência e Tecnologia - ICT, Univ Estadual Paulista - UNESP, São José dos Campos, SP, Brazil.

(b) Department of Dental Materials and Prosthodontics, Instituto de Ciência e Tecnologia - ICT, Univ Estadual Paulista UNESP, São José dos Campos, SP, Brazil.

(c) Department of Restorative Dentistry, Instituto de Ciência e Tecnologia - ICT, Univ Estadual Paulista - UNESP, São José dos Campos, SP, Brazil.

Declaration of Interests: The authors certify that they have no commercial or associative interest that represents a conflict of interest in connection with the manuscript.

Corresponding Author:

Júlia Magalhães Costa Lima

E-mail: jucostalima@hotmail.com

Submitted: Feb 08, 2013

Accepted for publication: Apr 29, 2013

Last revision: May 07, 2013
Abstract: The objective of this study was to evaluate the influence of different surface agents on the flexural strength of a ceramic system. Eighty bar-shaped specimens of zirconia were divided into four groups according to the agent to be used: group Control - to be cleaned with alcohol; group VM9 - application of a fluid layer of porcelain; group Effect Bonder - application of a bonding agent; and group Coloring Liquid - application of coloring liquid. All specimens received the porcelain application by the layering technique and were then subjected to thermocycling. The four-point bending test was performed to calculate the strength values $(\sigma, \mathrm{MPa})$ and the failure modes were classified. ANOVA did not detect significant differences among the groups. The Weibull modulus were 5 (Control, VM9 and Effect Bonder) and 6 (Coloring Liquid). The cracking of the porcelain ceramic toward the interface was the predominant failure mode. It was concluded that the surface agents tested had no effect on the flexural strength of the bilaminated ceramic specimens.

Descriptors: Ceramics; Compressive Strength; Dental Materials; Fractures, Stress.

\section{Introduction}

The growing interest in more aesthetic and biocompatible materials has led to the development of yttria-partially stabilized zirconia-based ceramic (Y-TZP) as an alternative to the metal infrastructures used in bilaminated restorations. The Y-TZP has superior mechanical properties when compared with those of other ceramics, ${ }^{1,2}$ with flexural strength values near $1000 \mathrm{MPa}$ and fracture toughness up to $80 \%$ higher than that of other ceramics. ${ }^{1,3}$

However, Y-TZP has limited aesthetics, due to its opacity. ${ }^{4}$ Therefore, the Y-TZP infrastructure should be covered with a compatible porcelain to provide a more natural-looking restoration. Despite the wide acceptance of Y-TZP as infrastructure in metal-free systems, and the several laboratory studies that sought an improvement in adhesion between this material and resin cement, clinical studies report that one great reason for failure is the delamination of the porcelain. ${ }^{5,6}$

Dyes based on $\mathrm{Fe}, \mathrm{Cu}, \mathrm{Co}$, and Mn oxides and opacifiers based on $\mathrm{Sn}$, $\mathrm{Zn}, \mathrm{Al}, \mathrm{Zr}$, and Ti oxides may be applied over the zirconia before sintering to improve its opacity and mask the color of the final restoration., However, there is still controversy about the effects of these dyes on the 


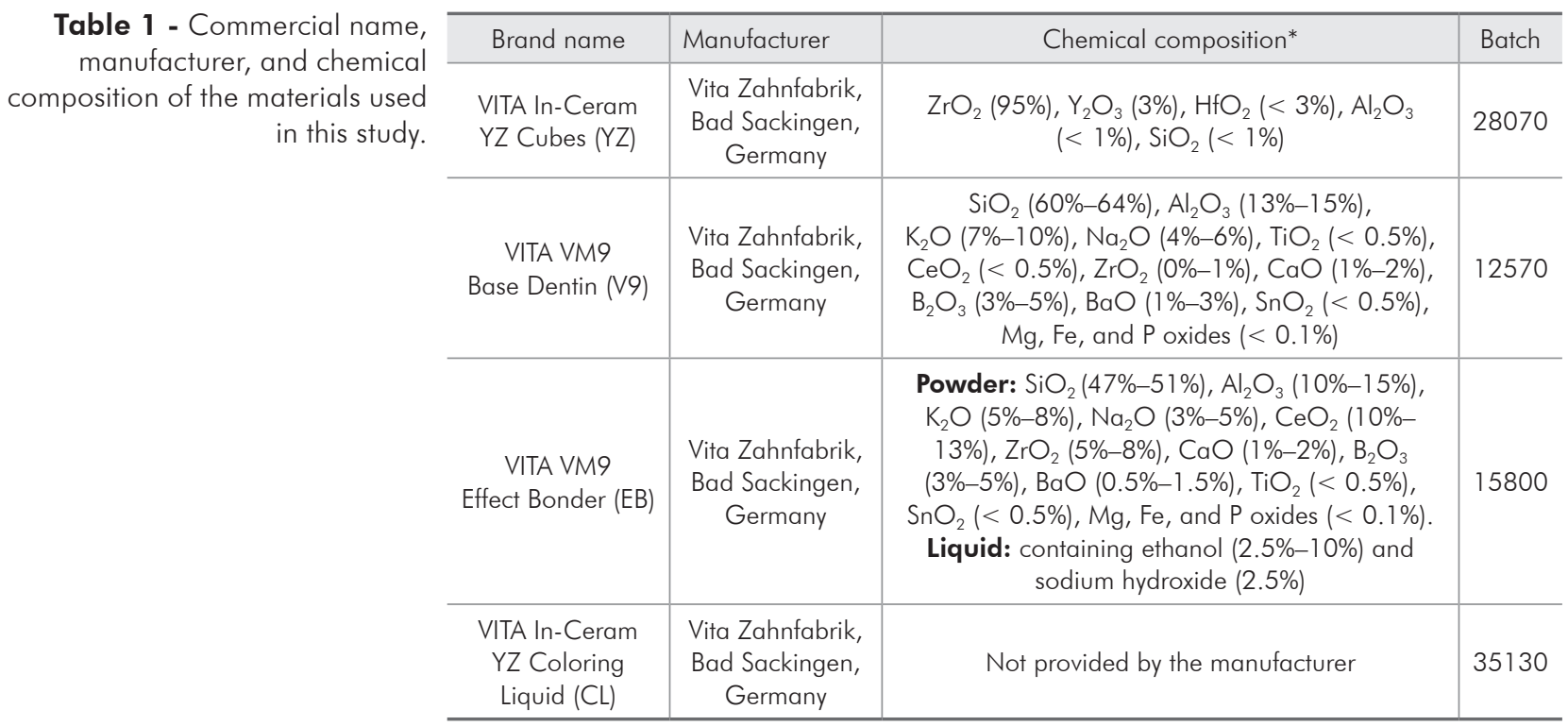

*Provided by the manufacturer.

flexural strength of Y-TZP and porcelain. In 2002, Ardlin ${ }^{9}$ reported that stained infrastructure showed higher flexural strength than non-colored zirconia. Hjerppe et al. ${ }^{8}$ in 2008 , found that the prolonged immersion of Y-TZP discs in the dyes led to a considerable reduction in biaxial flexural strength values, whereas Pittayachawan et al. ${ }^{10}$ found no effect of the different dyes on the flexural strength of $\mathrm{Y}$ TZP.

As an alternative to the use of dyes on Y-TZP infrastructure, the manufacturer recommends the use of a surface liner, the VITA VM9 Effect Bonder (Vita Zahnfabrik, Bad Sackingen, Germany). It should be applied after Y-TZP ceramic sintering and prior to porcelain application. Another important aspect to be considered is that the use of the coloring technique or the Effect Bonder on the Y-TZP is often overlooked by prosthodontics technicians during the laboratory phase. Borba et al. ${ }^{11}$ even assumed that the Effect Bonder has been replaced by a wash layer by the manufacturer. However, the influence of these joining materials on the flexural strength of Y-TZP/porcelain systems is unclear.

Thus, the objective of this study was to evaluate the influence of several surface agents on the flexural strength $(\sigma)$ of bilaminated specimens composed by Y-TZP and porcelain, to test the null hypothesis that these agents would not increase their flexural strength values and reliability.

\section{Methodology}

The commercial names, batch, manufacturers, and chemical compositions of the materials used in this study are described in Table 1.

\section{Specimen preparation}

Eighty bar-shaped specimens of pre-sintered YTZP were made with the post-sintering calculated dimensions of $20 \times 4 \times 1 \mathrm{~mm}$, and were divided into four groups $(n=20)$ according to the surface agent used:

- CT (control) - to be cleaned with isopropyl alcohol;

- V9 - fluid mixing-layer application of the VM9 porcelain powder and the modeling liquid (VITA Modeling Liquid, Vita Zahnfabrik);

- EB - layer application of the surface liner (VITA VM9 Effect Bonder Fluid, Vita Zahnfabrik); and

- CL - immersion for 2 minutes in Coloring Liquid (LL1, Vita Zahnfabrik), followed by drying.

Y-TZP bars from groups CT, V9, and EB were sintered prior to the application of surface agents in a VITA ZYrcomat T oven (Vita Zahnfabrik), while the bars from the CL group were sintered after application of the coloring agent. The specimens from 
the V9 and EB groups were subjected to the "Effect Bonder Burning" program in VITA VACUMAT 6000 MP (Vita Zahnfabrik).

All specimens received an application of VM9 porcelain by the layering technique to obtain a layer approximately $2.00 \mathrm{~mm}$ thick of VM9. The porcelain surface of each specimen was ground with wet sandpaper in sequence $(\# 120,400,600,800$, and 1200 ) in a polishing machine (Metaserver 3000, Buehler, Lake Bluff, USA) to standardize the specimens' dimensions and surfaces. They then received chamfers on the edges, and the specimens had the final dimensions of $20 \times 4 \times 3 \mathrm{~mm}$ (ISO 6872:2008), confirmed with a digital caliper (Starrett 797, L.S. Starrett Co., Athol, USA).

\section{Aging}

All specimens were subjected to 1800 thermocycles (between $5^{\circ} \mathrm{C}$ and $55^{\circ} \mathrm{C}, 30 \mathrm{~s}$ in each bath) and remained stored in distilled water at $37^{\circ} \mathrm{C}$ for 1 week prior to the mechanical tests.

\section{Four-point flexural strength test}

The bilaminated specimens were placed in the four-point bending test device with the porcelain surface tested under tensile loading. The device was placed in an EMIC DL 1000 universal testing machine (EMIC, São José dos Pinhais, Brazil), and the flexural strength test was performed at a speed of $0.5 \mathrm{~mm} / \mathrm{min}$ and a 1000-kgf-load cell.

The maximum load ( $\mathrm{P}$, in $\mathrm{N}$ ) was recorded through the sound technique, in others words, at the first sign of fracture verified by noise and changes in the load versus deflection curve, the test was interrupted. ${ }^{12}$

The strength values $(\sigma$, in $\mathrm{MPa})$ were calculated according to the equations 1, 2 and 3 described by Della Bona et al. ${ }^{13}$

$$
\sigma=\left[\left(\frac{\mathrm{P}}{2}\right)\left(\frac{\mathrm{L}}{3}\right) \mathrm{Y}^{\prime}\right] / \mathrm{I}_{\text {TOT }}
$$

where $P$ is the applied load in Newtons $(\mathrm{N}), L$ is the distance in millimeters $(\mathrm{mm})$ between the support rollers, $Y$ ' is the distance in $\mathrm{mm}$ from the neutral axis to the outermost fiber, and $I_{\mathrm{TOT}}$ is the moment of inertia of the cross-section about the central axis.

The Y'value was determined by equation 2 :

$$
\left.Y^{\prime}=\left[\left(\frac{\mathrm{t}_{\mathrm{c}}^{2}}{2}\right)+\frac{\mathrm{E}_{\mathrm{v}}}{\mathrm{E}_{\mathrm{c}}\left(\left(\frac{\mathrm{t}_{\mathrm{v}}^{2}}{2}\right)+\mathrm{t}_{\mathrm{c}} \mathrm{t}_{\mathrm{v}}\right)}+\frac{\mathrm{E}_{\mathrm{g}}}{\mathrm{E}_{\mathrm{c}}\left(\left(\frac{\mathrm{t}_{\mathrm{g}}^{2}}{2}\right)+\mathrm{t}_{\mathrm{g}} \mathrm{t}_{\mathrm{v}}+\mathrm{t}_{\mathrm{g}} \mathrm{t}_{\mathrm{c}}\right)}\right] / \mathrm{t}_{\mathrm{c}}+\left(\frac{\mathrm{E}_{\mathrm{v}}}{\mathrm{E}_{\mathrm{c}}}\right) \mathrm{t}_{\mathrm{v}}+\left(\frac{\mathrm{E}_{\mathrm{g}}}{\mathrm{E}_{\mathrm{c}}}\right)+\mathrm{t}_{\mathrm{g}}\right]
$$

where $t_{c}, t_{v}$, and $t_{g}$ correspond to the thicknesses $(t$, in $\mathrm{mm})$ of the infrastructure ceramic, veneer ceramic, and glaze layers, respectively, and $E_{c}$, $E_{v}$, and $E_{g}$ are the elastic moduli $(E)$ of the infrastructure, veneer ceramic, and glaze layers, respectively.

The variable $I_{\text {ТОТ }}$ was determined by equation 3 :

$$
I_{\text {Tot }}=\left\{\begin{array}{l}
{\left[\left(\frac{1}{12}\right)\left(\frac{E_{g}}{E_{c}}\right) w_{g}^{3}\right]+\left[\left(\frac{E_{g}}{E_{c}}\right) w_{g}\left(t_{c}+t_{v}+\left(\frac{t_{g}}{2}\right)-Y^{\prime}\right)^{2}\right]+\left[\left(\frac{1}{12}\right)\left(\frac{E_{v}}{E_{c}}\right) w_{v}^{3}\right]+} \\
{\left[\left(\frac{E_{v}}{E_{c}}\right) w_{t_{v}}\left(t_{c}+\left(\frac{t_{v}}{2}\right)-Y^{\prime}\right)^{2}\right]+\left[\left(\frac{1}{12}\right) w_{c}^{3}\right]+\left[w_{c}\left(\left(\frac{t_{c}}{2}\right)-Y^{\prime}\right)^{2}\right]}
\end{array}\right\}
$$

where $w$ is the full width of the sample.

The thicknesses of the materials were measured with a digital caliper, and the moduli values were obtained from the literature, these being equal to 209.3 GPa for Y-TZP and 66.5 GPa for VM9. ${ }^{11}$ The glaze layer was not used in this study, and therefore the values for this material were considered to be zero.

\section{Failure mode analysis}

The tested specimens were evaluated by stereomicroscopy (40×, CBB Olympus, Tokyo, Japan) to determine the failure mode among cracks in the porcelain toward the interface, delamination or chipping of the porcelain and catastrophic fracture. The characteristics of each of those failures were described by Benetti et al. ${ }^{12}$ Some scanning electron microscopy (SEM) images were obtained to show microscopic features of the tested specimens.

\section{Statistical analysis}

The $\sigma$ data were statistically analyzed by oneway analysis of variance (ANOVA) $(p<0.05)$ and 
Table 2 - Flexural strength mean $(\sigma)$ and standard deviation (SD) values, Weibull distribution values including the Weibull modulus (m), characteristic strength $\left(\sigma_{0}\right)$, probability of failure at $5 \%\left(\sigma_{0.05}\right)$ and at $1 \%\left(\sigma_{0.01}\right)$ and correlation coefficient (CC) for all experimental groups. The failure mode distribution (number of specimens per group) for each group is also shown.

\begin{tabular}{c|c|c|c|c|c|c|c|c}
\hline Groups & Mean (SD) & $\mathrm{m}$ & $\sigma_{0}$ & $\sigma_{0.05}$ & $\sigma_{0.01}$ & $\mathrm{C}$ & $\mathrm{Ch} / \mathrm{De}$ & Cat \\
\hline $\mathrm{CT}$ & $40.45(9.63)$ & 5 & 44.16 & 23.76 & 16.91 & 14 & 3 & 3 \\
\hline V9 & $38.20(8.07)$ & 5 & 41.40 & 24.04 & 17.84 & 14 & 4 & 2 \\
\hline EB & $36.49(8.85)$ & 5 & 39.89 & 21.19 & 14.98 & 16 & 0 & 4 \\
\hline CL & $41.65(8.00)$ & 6 & 44.87 & 27.48 & 21.00 & 15 & 1 & 4 \\
\hline
\end{tabular}

CT: control; V9: VM9 fluid; EB: Effect Bonder; CL: coloring liquid. C: cracking; Ch/De: chipping and delamination; Cat: catastrophic.

Table 3 - One-way ANOVA test for flexural strength values $(p<0.05)$.

the Weibull distribution, followed by the chi-square test for equal parameters.

\section{Results}

The data were normally and homogeneously distributed according to the Shapiro-Wilk-Levene test. Flexural strength means and standard deviation values are summarized in Table 2.

The predominant mode of failure was cracking of the porcelain reaching the interface (Figure 1A, B). The cohesive failure of the porcelain (chipping) was always accompanied by some delamination at the interface (Figure 2A, B). The Weibull parameters are also presented in Table 2. The greatest Weibull modulus was observed in CL $(m=6)$, followed by V9, CT, and EB $(m=5)$. No differences in Weibull modulus were found among groups $(\mathrm{p}=0.800)$, and no significant differences in mean $\sigma$ values (in $\mathrm{MPa}$ ) were found ( $p=0.235$ ) (Table 3).

\section{Discussion}

The union between zirconia and porcelain is unclear and not well-understood, although it is of paramount importance to the success of all-ceramic restorations. Several studies have been performed in attempts to understand this union. ${ }^{11,12,14}$ In the present study, the procedure was to evaluate the effect of various surface agents on the porcelain/zirconia system.

Due to the fact that brittle materials are much weaker under tensile than under compression stress, an important indicator of a material's mechanical properties is the flexural strength. ${ }^{15}$ The fourpoint flexural strength test was used in this study because it offers a more controlled environment for

\begin{tabular}{c|c|c|c|c|c}
\hline & $\begin{array}{c}\text { Sum of } \\
\text { squares }\end{array}$ & $\mathrm{df}$ & $\begin{array}{c}\text { Mean } \\
\text { square }\end{array}$ & $f$ & Sig. \\
\hline $\begin{array}{c}\text { Between } \\
\text { groups }\end{array}$ & 305,111 & 3 & 101,704 & 1,451 & 0,235 \\
\hline $\begin{array}{c}\text { Within } \\
\text { groups }\end{array}$ & 5328,658 & 76 & 70,112 & & \\
\hline Total & 5633,769 & 79 & & & \\
\hline
\end{tabular}

evaluating the mechanical properties of the ceram$\mathrm{ics}^{16}$ and allows for greater discrimination between and among the different ceramic materials, resulting in statistically significant differences. ${ }^{17}$ Although this test provides strength values lower than those provided by the three-point test, ${ }^{17}$ it may represent a more reliable and realistic approach. ${ }^{18}$

The thin-layer application of the porcelain fluid mixture had no significant effect on the flexural strength between porcelain and Y-TZP in the present study, as observed by shear testing in a previous work. ${ }^{19}$

With respect to the EB, an application recommended by the manufacturer to ensure color reliability and to improve bonding between the YZ infrastructure and the porcelain, the use of EB did not improve the flexural strength of the set, which was also observed in previous studies. ${ }^{11,12}$

Indications for the use of CL are also contradictory and scarce in the literature. While one study reported increased flexural strength of the colored infrastructure compared with the unstained Y-TZP, ${ }^{10}$ another study did not observe any influence on these values, ${ }^{10}$ which agrees with results from the present study. There is also a report of a reduction in Y-TZP strength values after prolonged immersion in dye solutions. ${ }^{8}$ 

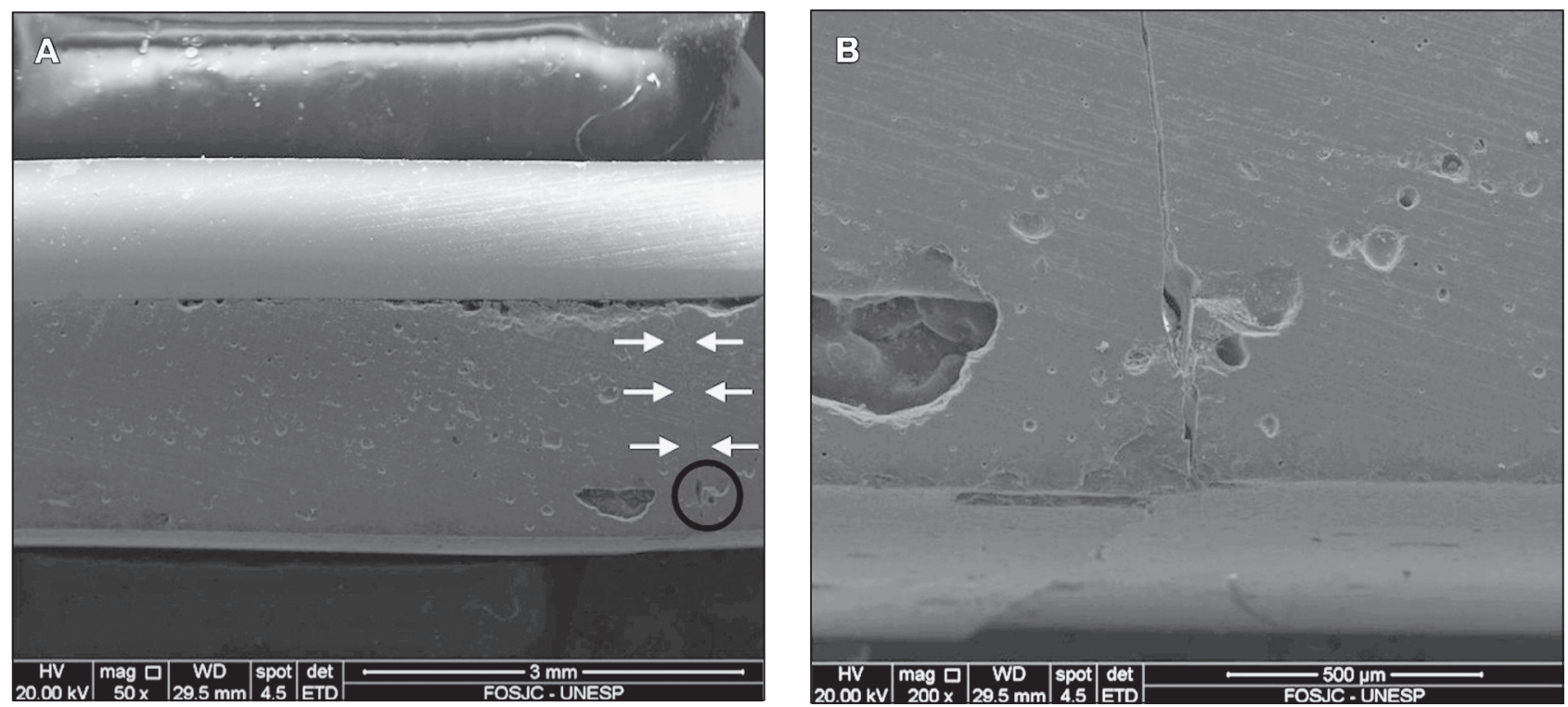

Figure 1- A: The crack starts on the tensile side and propagates to the interfacial area, as shown by the white arrows (50x). B: A closer view (200x) of the circle in Figure 1A. The tensile side is facing downwards.
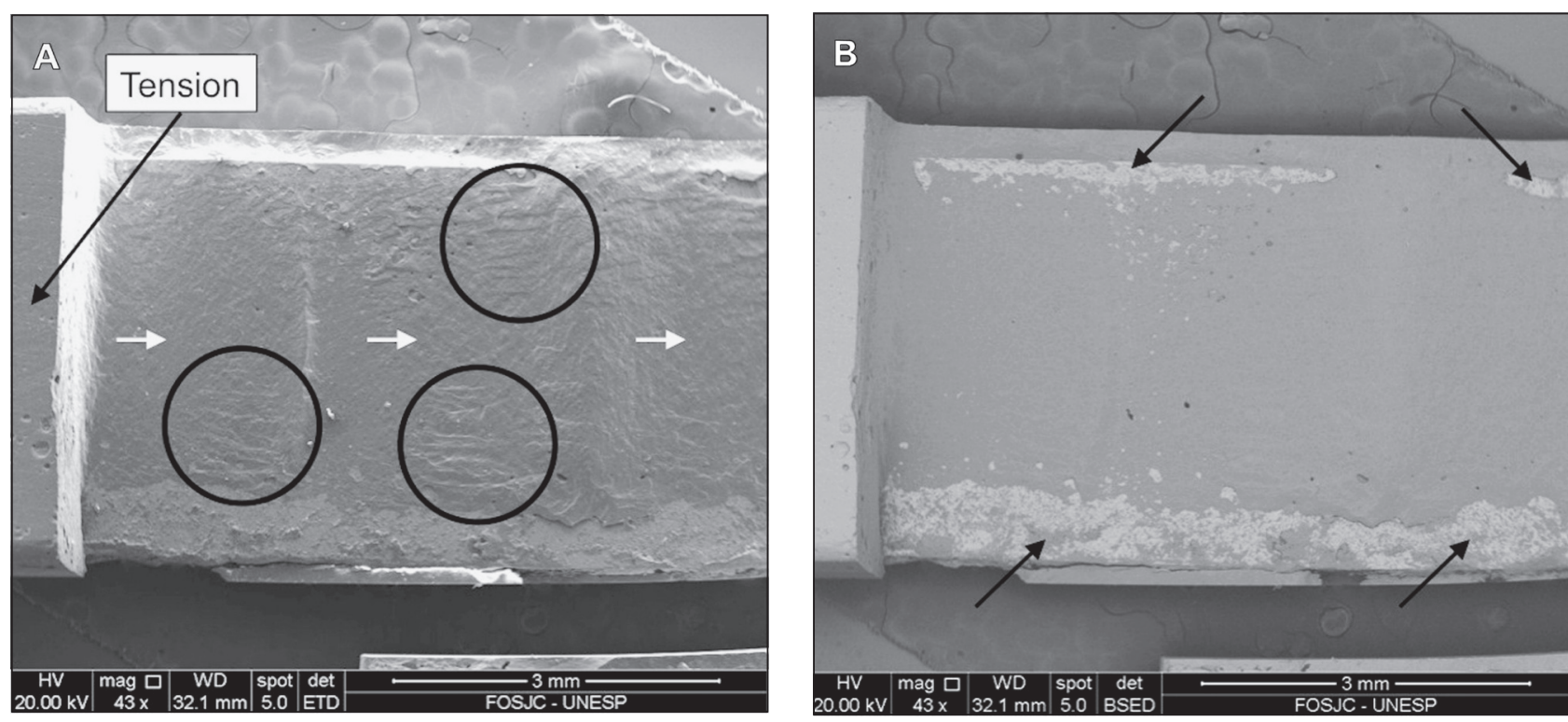

Figure 2 - A: Image of a control specimen showing cohesive failure and delamination of the porcelain (43x). The twist hackles displayed in the circles indicate the direction of crack propagation (white arrows). B: Image of a control specimen showing cohesive failure and delamination of the porcelain (43x). Delamination is observed close to the bar edges (arrows).

Although it has been said that the water present in the surface agents can propitiate higher phase transformation of zirconia grains in contact with the porcelain, thus causing failures, ${ }^{20}$ Hjerppe et al. ${ }^{21}$ found no phase transformation with energydispersive $\mathrm{x}$-ray spectroscopy (EDS) analysis of the zirconia surface after sintering of a coloring liquid.
This possibly explains the reason why no significant differences were found between experimental and control groups in the current study, leading to rejection of the null hypothesis.

Cohesive failures such as porcelain chipping are likely to occur due to tensile stresses associated with residual thermal stresses. ${ }^{22}$ For the zirconia- 
porcelain combination, despite the small difference in thermal expansion coefficients, the low thermal diffusivity of the zirconia results in a high temperature difference and very high residual tensile stresses within the porcelain. ${ }^{22,23}$ To some extent, this tensile stress is compensated by compression stress, but when excessive loads are applied, the tensile stress is higher and may lead to immediate crack development, increasing the likelihood of fracture. ${ }^{22,24} \mathrm{Clin}-$ ically, it has been observed that bilaminated crown failure occurs most frequently by the chipping of the porcelain. . $^{25,6,25,26}$ In the present study, the failure mode analysis revealed a predominance of failure with porcelain cracking, corroborated by the results of another laboratory study. ${ }^{12}$ The fact that the cracks found intra-orally are not as easily detected justifies this difference. The perception of the crack in this condition depends on its extent and location, and often the failure becomes noticeable only when there is progression to chipping. Moreover, as we made use of the sound emission technique to detect the failure, ${ }^{12}$ complete fracture of the porcelain was hardly seen.

Guess et al. ${ }^{27}$ suggested that delamination would be a consequence of zirconia's resistance to crack propagation or poor bond between zirconia and porcelain. Additionally, finite element analysis showed that an incomplete union between these two ceramics increases (up to 12 times) the stress concentration in the porcelain, ${ }^{28}$ whose mechanical properties are known to be lower than those of the infrastructure. Therefore, some effort has been made to improve this union, such as using a thin layer of glass between the materials. ${ }^{29}$ In this case, a less frequent occurrence of delamination was observed, showing that there was an enhancement of the bonding. Similarly, we made use of an intermediate material that could wet better the porcelain in the experimental groups. However, delamination

\section{References}

1. Tinschert J, Zwez D, Marx R, Anusavice KJ. Structural reliability of alumina-, feldspar-, leucite-, mica- and zirconiabased ceramics. J Dent. 2000 Sep;28(7):529-35. was the least frequent type of failure in all groups, thus showing that bonding between porcelain and zirconia doesn't seem to constitute the "Achilles' heel" for restorations made with these materials, as also stated elsewhere. ${ }^{20}$ The fracture site of a control specimen shows that the fracture ran inside the porcelain with little delamination close to the edges (Figure 2B).

High values of Weibull modulus (m) indicate that there is less variability among the strengths in the same group and a greater integrity of the material. ${ }^{30}$ Although the $\mathrm{m}$ values obtained were within the expected range of reliability for ceramic materials, between 5 and $15,{ }^{30}$ the low modulus found for all groups indicates that none of the intermediate materials was able to improve the flexure strength of the bi-layered specimens. Plus, no significant differences were found among the Weibull moduli $(\mathrm{m})$ of the tested groups, with overlap of the confidence intervals. The causes of failure of all-ceramic restorations have not been fully understood and are believed to be multifactorial. It is suggested that further studies should be conducted, especially concerning the causes and effects of the thermal stresses, so that porcelain failure on zirconia frameworks can be clarified and minimized.

\section{Conclusion}

The surface agents used to improve the color and the bonding between infrastructure and porcelain had no significant effect on the flexural strength and on the failure mode of the specimens. This study suggests that the use of surface agents did not interfere in the fracture behavior of bilaminated restorations.

\section{Acknowledgements}

The authors thank the Fundação de Amparo à Pesquisa do Estado de São Paulo (FAPESP) for the financial support (grant \# 2011/13085-9).

2. Sailer I, Fehér A, Filser F, Gauckler LJ, Lüthy H, Hämmerle CHF. Five-year clinical results of zirconia frameworks for posterior fixed partial dentures. Int J Prosthodont. 2007 JulAug;20(4):383-8. 
3. Sundh A, Molin M, Sjögren G. Fracture resistance of yttrium oxide partially-stabilized zirconia all-ceramic bridges after veneering and mechanical fatigue testing. Dent Mater. 2005 May;21(5):476-82.

4. Heffernan MJ, Aquilino SA, Diaz-Arnold AM, Haselton DR, Stanford CM, Vargas MA. Relative translucency of six all-ceramic systems. Part I: core materials. J Prosthet Dent. 2002 Jul;88(1):4-9.

5. Raidrodski AJ, Chiche GJ, Potiket N, Hochstedler JL, Mohamed SE, Billiot S, et al. The efficacy of posterior three-unit zirconium-oxide-based ceramic fixed partial dental prostheses: A prospective clinical pilot study. J Prosthet Dent. 2006 Oct;96(4):237-44.

6. Christensen RP, Ploeger BJ. A clinical comparison of zirconia, metal and alumina fixed-prosthesis frameworks veneered with layered or pressed ceramic. A three-year report. J Am Dent Assoc. 2010 Nov; 141(11):1317-29.

7. Milleding P, Karlsson S, Nyborg L. On the surface elemental composition of non-corroded and corroded dental ceramic materials in vitro. J Mater Sci Mater Med. 2003 Jun;14(6):55766.

8. Hjerppe J, Närhi T, Fröberg K, Vallittu PK, Lassila LVJ. Effect of shading the zirconia framework on biaxial strength and surface microhardness. Acta Odontol Scand. 2008 Oct;66(5):262-7.

9. Ardlin BI. Transformation-toughened zirconia for dental inlays, crowns and bridges: chemical stability and effect of lowtemperature aging on flexural strength and surface structure. Dent Mater. 2002 Dec;18(8):590-5.

10. Pittayachawan P, McDonald A, Petrie A, Knowles JC. The biaxial flexural strength and fatigue property of Lava Y-TZP dental ceramic. Dent Mater. 2007 Aug;23(8):1018-29.

11. Borba M, Araújo MD, Lima E, Yoshimura HN, Cesar PF, Griggs JA, et al. Flexural strength and failure modes of layered ceramic structures. Dent Mater. 2011 Dec;27(12):1259-66.

12. Benetti P, Pelogia F, Valandro LF, Bottino MA, Della Bona A. The effect of porcelain thickness and surface liner application on the fracture behavior of a ceramic system. Dent Mater. 2011 Sep;27(9):948-53.

13. Della Bona A, Anusavice KJ, DeHoff PH. Weibull analysis and flexural strength of hot-pressed core and veneered ceramic structures. Dent Mater. 2003 Nov;19(7):662-9.

14. Kon M, Ishikawa K, Kuwayama N. Effects of zirconia addition on fracture toughness and bending strength of dental porcelains. Dent Mater J. 1990 Dec;9(2):181-92.

15. Bottino MA, Salazar-Marocho SM, Leite FP, Vásquez VC, Valandro LF. Flexural strength of glass-infiltrated zirconia/ alumina-based ceramics and feldspathic veneering porcelains. J Prosthodont. 2009 Jul;18(5):417-20.

16. Aboushelib MN, Kleverlaan CJ, Feilzer AJ. Evaluation of a high fracture toughness composite ceramic for dental applications. J Prosthodont. 2008 Out;17(7):538-44.
17. Fischer J, Stawarczyk B, Hämmerl CHF. Flexural strength of veneering ceramics for zirconia. J Dent. 2008 May;36(5):31621.

18. Rodrigues Junior SA, Ferracane JL, Della Bona A. Flexural strength and Weibull analysis of a microhybrid and a nanofill composite evaluated by 3- and 4-point bending tests. Dent Mater. 2008 Mar;24(3):426-31.

19. Fischer J, Stawarczyk B, Sailer I, Hämmerle CHF. Shear bond strength between veneering ceramics and ceria-stabilized zirconia/alumina. J Prosthet Dent. 2010 May;103(5):267-274.

20. Tholey MJ, Swain MV, Thiel N. SEM observations of porcelain Y-TZP interface. Dent Mater. 2009 Jul;25(7):857-62.

21. Hjerppe J, Vallittu PK, Fröberg K, Lassila LV. Effect of sintering time on biaxial strength of zirconium dioxide. Dent Mater. 2009 Feb;25(2):166-71.

22. Swain MV. Unstable cracking (chipping) of veneering porcelain on all-ceramic dental crowns and fixed partial dentures. Acta Biomater. 2009 Jun;5(5):1668-77.

23. Kelly JR, Giordano R, Pober R, Cima MJ. Fracture surface analysis of dental ceramics: clinically failed restorations. Int J Prosthodont. 1990 Sep-Oct; 3(5):430-40.

24. Choi JE, Neil Waddell J, Torr B, Swain MV. Pressed ceramics onto zirconia. Part 1: Comparison of crystalline phases present, adhesion to a zirconia system and flexural strength. Dent Mater. 2011 Dec;27(12):1204-12

25. Tinschert J, Schulze KA, Natt G, Latzke P, Heussen N, Spiekermann H. Clinical behavior of zirconia-based fixed partial dentures made of DC-Zirkon: 3-year results. Int J Prosthodont. 2008 May-Jun;21(3):217-22.

26. Sailer I, Fehér A, Filser F, Lüthy H, Gauckler LJ, Schärer P, et al. Prospective clinical study of zirconia posterior fixed partial dentures: 3-year follow-up. Quintessence Int. 2006 Oct;37(9):685-93.

27. Guess PC, Kulis A, Witkowski S, Wolkewitz M, Zhang Y, Strub JR. Shear bond strengths between different zirconia cores and veneering ceramics and their susceptibility to thermocycling. Dent Mater. 2008 Nov;24(11):1556-67.

28. Rocha EP, Anchieta RB, Freitas Junior AC, Almeida EO, Cattaneo PM, Ko CC. Mechanical behavior of ceramic veneer in zirconia-based restorations: A 3- dimensional finite element analysis using microcomputed tomography data. J Prosthet Dent. 2011 Jan;105(1):14-20.

29. Saied MA, Lloyd IK, Haller WK, Lawn BR. Joining dental ceramic layers with glass. Dent Mater. 2011 Oct;27(10):1011-6.

30. Della Bona A. Characterizing ceramics and the interfacial adhesion to resin: the relationship of microstructure, composition, properties and fractography. J Appl Oral Sci. 2005 Mar;13(1):1-9. 